\title{
肝ペルオキシゾーム増殖誘導剤に共通する基本的化学構造
}

\section{Essential Chemical structure of Liver Peroxisome Proliferators}

\author{
池 田 敏 彦 \\ 三共株式会社分析代謝研究所 $\overline{\text { T1 }} 140$ 東京都品川区広町1-2-58
}

\begin{abstract}
Summary
Since chemical structures of peroxisome proliferators are so much versatile, it has been difficult to identify the essential chemical form required for the induction of peroxisome proliferation. From the fact that perfluorinated fatty acids (C 10, C 8 and $\mathrm{C} 4$ ), the un-metabolizable derivatives of fatty acids, induced the peroxisome proliferation markedly in rat liver, the free fatty acids were considered as the true inducer. Perfluoroalkanes ( $\mathrm{C} 12$ and $\mathrm{C} 8$ ) which possess no functional groups did not show any inducing activity, supporting this concept. Although the CoA form of fatty acids have been claimed as the intrinsic form for the peroxisome proliferator, this possibility should be negligible because perfluorooctane sulphonate, another unmetabolizable compound which is never converted into CoA form, induced the peroxisome proliferation. From these results, we have come to the conclution that the un-metabolizable lipophilic anion is the essential chemical structure common in the peroxisome proliferators. All of the known peroxisome proliferators are included into this category, as such or after receiving metabolism.
\end{abstract}

\section{いけだ としひこ}

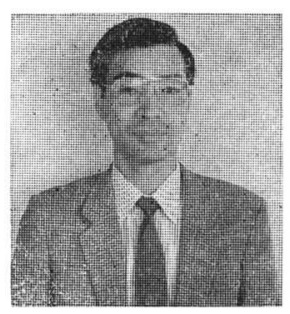

1972年 3 月に京都大学大学院工学研究科工業化学専攻修士課程を終了後, 三共㧣分析代謝 研究所 (当時中央研究所・薬物代謝 研究室) の一員に加兄て頂き, 現在にいたって招りま す. 在学した工業生化学研究室 (福井三郎教授) では, 当時助手の田中渥夫先生 (現教授) がアルカン生育酵母に扔けるペルオキシゾーム増殖誘導現象を発見され, 精力的に研究され 始めたところでした．薬物代謝の研究室でペルオキシゾームにかかわりを持つことがあるら とは夢にも思いませんでしたが，たまたま仕事で取り扱った薬物が動物でペルオキシゾーム 増殖誘導を引き起こしたことから，この分野にも興味を持つょらになりました，入社以来， 標識薬物 $\left({ }^{14} \mathrm{C},{ }^{3} \mathrm{H}\right)$ を用い，いわゆる ADME 試験に精力を注いできましたが，入社する前 に考觉ていた汪どルーティン業務的な要素は少なく, 面白い薬物代謝反応にぶつかることが 何度かあって, 人間関係も含めて大変エキサイティングな毎日を送らさせて頂いて特りま す. 現在は, そのうちの一つである薬物の脂肪酸抱合反応に力を注いでいこうと考壳ていま す. 幸い上司と会社の御理解を得て, 1981 年から 1983 年の 2 年間, 米国国立衛生 研究所 (NIH) の Dr. D.W. Nebert のもとに留学し, チトクローム P-450 に拈ける分子生物学 的な手法を学ぶと共に, 大いにアメリカ生活をエンジョイしてきました. 数年前まではギタ 一を弾いたり，バドミントンをしたりするのが趣味でしたが，現在では研究室の同僚とビー ルを飲んで語るのが主な楽しみの一つです. 


\section{1. はじめに}

脂質低下薬として知られているクロフィブレー トが，ラット肝ペルオキシゾームの増殖を誘導す ることが報告されて以来 ${ }^{11}$ ，化学構造の異なった さまざまなペルオキシゾーム増殖誘導剤が, 現在 にいたるまで数多く報告されてきている（Fig. $1)^{2,3)}$. な打 細胞内で，ある酵素蛋白が新たに合 成されて酵素量が増加する現象には, 誘導 (Induction）と言う術語が使用されるが，クロフィブ レートによるペルオキシゾームの増加や，メタピ リレンによるミトコンドリアの増加といったよう に，まとまりのある形をしたオルガネラが増加す る場合には，増殖 (Proliferation) といら術語が 使用されている。そこでこうした作用を持つ薬剤 を, ここでは増殖誘導剤 (Proliferator) と呼ぶこ とにする。

多彩な化学構造と同様に, ペルオキシゾーム増

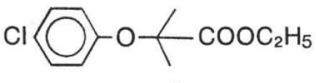

クロフィブレート

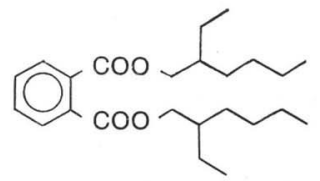

ジエチルヘキシルフタレート

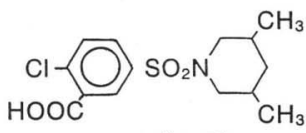

チブリン酸

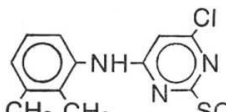

WY-14643

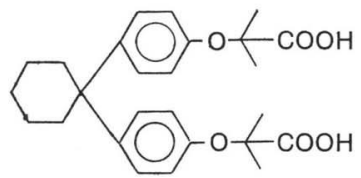

クリノフィブレート
殖誘導剤の持つ薬理作用や用途もバラェティーに 富んで拉り，プラスチックの可塑剂であるジェチ ルヘキシルフタレート, 抗炎症剤のチブル酸, 抗 てんかん剤のバルプロ酸, 血糖降下薬のクロルフ ェニルペンチルオキシランカルボキシレートなど 数多くのものが知られている.こうしたペルオキ シゾーム増殖誘導片の有する毒性学上の問題点 や，肝に対する種々の影響等については，すでに 本誌でも詳しく総説されているのでそちらを参照 されたい4).

ペルオキシゾーム増殖誘導剤は, さまざまな化 学構造を持ち, かつその代謝物も増殖誘導活性を 有する可能性があるので, その中から共通した化 学構造を抽出することは非常に困難である。この ミニレビューでは, 多岐にわたる化学構造のう ち，本質的にペルオキシゾーム増殖誘導の引金を 引くと考兄らる化学構造について, われわれの 研究結果から考察してみたい。

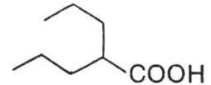

バルプロ酸<smiles>CCCCC(CC)C(=O)O</smiles>

2-エチルヘキサン酸

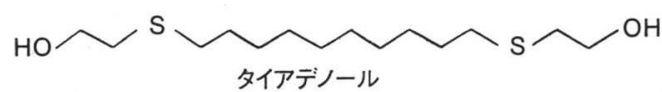

2[5(4-クロルフェニル)ペンチル $]$ オキシラン-2-カルボキシレート

$\mathrm{CH}_{2} \mathrm{OH}$

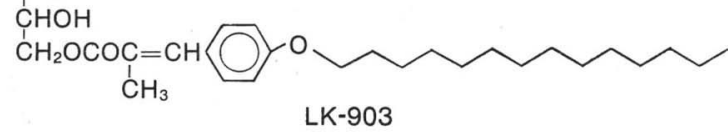

$\mathrm{HOOC}_{\mathrm{RMI}-14514}^{\mathrm{O}} \mathrm{N}^{\mathrm{O}}$

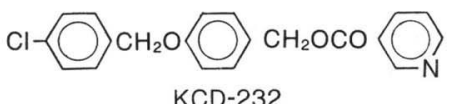

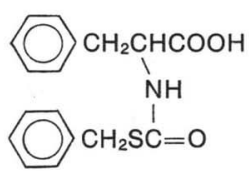

KF1492

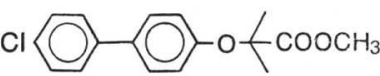

メチルクロフェナベート 


\section{2. 酵素誘導に対する一般的考察}

大腸菌に和けるラクトースオペロン説に見られ るごとく, 酵素誘導の基本的な考兄方は, 動物細 胞に执いてもやはり「基質誘導」であろう。つま り, 誘導酵素は普段は低濃度でしか細胞内に存在 しないが，その酵素の基質の投与により蛋白の合 成が刺激され，大量の酵素がその基質を代謝する 目的で誘導されてくると言う考方方である。緊急 時以外には無䭾な蛋白合成を不必要に行わないで おこらといら自然の節約原理が働いているものと 想像される. 良く知られているフェノバルビター ルによる薬物代謝酵素（チトクローム P-450）の 誘導現象も, この範疇に属するものと言える.

この考方方をペルオキシゾーム増殖誘導に当て はめようとしたとき, ペルオキシゾームは細胞が 生理的な代謝を行っている際, どういら役割を担 っているのかといら点が問題となる. コントロー ル肝に存在しているペルオキシゾームには, カタ ラーゼを初めとして尿酸酸化酵素, L- $\alpha$-ヒドロキ シ酸酸化酵素, セリンーピルビン酸アミノ基転移 酵素, カルニチンアセチル転移酵素, 脂肪酸 $\beta$ 酸 化系酵素群など, 何種類もの酵素が含まれてい る.技とらくこの数はペルオキシゾームの研究が 進むに従って, さらに増加するであろう。な打へ ルオキシゾームに存在するセリンーピルビン酸ア ミ)基転移酵素や脂肪酸 $\beta$ 酸化系酵素は, ミトコ ンドリアのそれとは全く異なった酵素群であるこ そが明らかになっている ${ }^{5,6)}$.

クロフィブレートにより増殖誘導を受けたペル オキシゾームは，コアと呼ばれる構造を持たず， カタラーゼ含量も低いなど, コントロールのもの とはかなり異なっており, かわりに脂肪酸 $\beta$ 酸化 系酵素含量が非常に高くなっているのが特徴であ る ${ }^{7)}$ これはペルオキシン゙ーム増殖誘導剤が例外 なく脂質低下作用を持つことの理由ともされてい る.このことからペルオキシゾームは本来の役割 の一つとして脂肪酸の代謝を行って沶り, 増殖誘 導剤はペルオキシゾームに存在する脂肪酸代謝を 行ら一連の酵素の遺伝子発現を刺激するものであ ることが強く示唆される.

\section{3. 脂肪はペルオキシジーム増殖誘導剩である か}

そこで, 先ほどの基質誘導の考方方に戻れば， 本来のペルオキシゾーム増殖誘導剤は, 脂肪ある いは脂肪酸ではないかと想像することができる。 事実，30\%脂肪含量といら高脂肪食を与光続ける と, 肝ペルオキシゾームが増殖することが報告さ れている ${ }^{8,9)}$. 動物を絶食したり，アロキサンによ る実験的糖尿病にして, 糖からのエネルギ一調達 を困難な状態にすると, 肝ペルオキシゾームが増 殖することも知られている ${ }^{10,11)}$. これは脂肪酸代 謝によるエネルギー産生を充進させる目的のため に, ペルオキシン゙ームが増殖誘導されると考光る と合理的な説明がつく. しかし, 脂肪による増殖 誘導の程度は非常に低く，30\%高脂肪食の長期投 与の結果, 肝細胞内に脂肪滴が充満しているよう な脂肪肝状態になっても, 増殖誘導の程度は 0.2 \%クロフィブレート混䬣投与で引き起こされるも のに遥かに及ばない。こうした実験で, 投与され ている脂肪は脂肪酸ではなく, トリグリセリドの 形であるので, トリグリセリドは，特そらく本来 の誘導剤ではないのであろらと考えることができ る.

\section{4. 遊離脂肪酸がペルオキシゾーム増殖誘導剤 であるか}

それでは，トリグリセリドではなく遊離の脂肪 酸が実際には誘導を引き起こしているのではない かという可能性が次に考えられる。 今までに報告 されているペルオキシゾーム増殖誘導剤が，例外 なくカルボン酸かあるいは代謝されてカルボン酸 になる官能基を有する化合物である事実は，この 可能性を考兄る上で非常に重要である，例宇ば， われわれは分岐鎖アルカンである $2,2,4,4 ， 6$, 8, 8-ヘプタメチルノナンが, ラット肝ペルオキ シゾームを誘導し, 肝蔵内にはそのジカルボン酸 型の代謝物である $2 ， 2 ， 4 ， 4 ， 6 ， 8 ， 8$-ヘプタメ チルノナンジカルボン酸が遊離型で主代謝物とし て検出されることを報告した（Table I, Fig. $2)^{12,13)}$. 脂肪酸に類似したこの代謝物は, カルボ キシル基の $\alpha$ 位に 2 つメチル基があるために, これ以上 $\beta$ 酸化されず，また脂溶性も高いため 
Table I. 2，2，4，4，6，8，8-ヘキサメチルノナン投与後の

肝臓ペルオキシゾーム酵素の誘導

\begin{tabular}{|c|c|c|}
\hline 酵 & コントロール & $\begin{array}{l}2,2,4,4,6,8,8 \text {-ヘキ } \\
\text { サメチルノナンa) }\end{array}$ \\
\hline カタラーゼ $\left(\mu \mathrm{mol}-\mathrm{H}_{2} \mathrm{O}_{2} / \mathrm{min} / \mathrm{mg}-\text { protein }\right)^{\mathrm{b})}$ & $675.1 \pm 33.1$ & $920.9 \pm 71.8^{*}$ \\
\hline カルニチンーアセチル転移酵素 (units/mg-protein)c) & $6.52 \pm 1.50$ & $62.7 \pm 7.78^{* *}$ \\
\hline シアン非感受性パルミトイル CoA 酸化酵素 ( II)d) & $0.878 \pm 0.064$ & $8.79 \pm 1.16^{* *}$ \\
\hline カルニチンーパルミトイル転移酵素 ("I)e) & $11.7 \pm 2.00$ & $58.8 \pm 5.90^{* *}$ \\
\hline
\end{tabular}

a : $1 \%-2,2,4,4,6,8,8$-ヘキサィチルノナン含有食で 2 週間飼育 $(\mathrm{n}=6)$.

$\mathrm{b}$ : ペルオキシゾームマーカー酵素. c c : ペルオキシゾームとミトコンドリアの両方に存在.

$\mathrm{d}$ ：ペルオキシゾーム酵素. $\quad \mathrm{e} ：$ ミトコンドリア酵素.

$*: \mathrm{p}<0.05 . \quad * *: \mathrm{p}<0.01$.

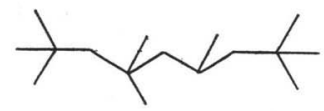

2、2、4、4、6、8、8-ヘプタメチルノナン
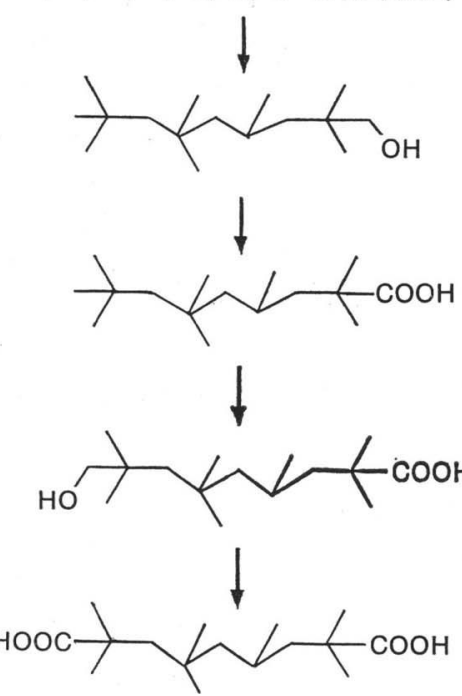

2、2、4、4、6、8、8-ヘプタメチルノナンジカルボン酸

Fig. 2. 2，2，4，4，6，8，8-ヘプタメチルノナ ンの肝蔵内主代謝物. $2,2,4,4,6,8$, 8-ヘプタメチルノナンジカルボン酸の生 成経路

(エーテルに可溶) 肝臓内に留まっているものと 思われる.しかし，これまでにパルミチン酸やス テアリン酸などのよらな通常の内因性脂肪酸を大 量投与して，ペルオキシゾーム増殖誘導が観察さ れたと言ら報告はない。この原因は，おそらく吸 収された時点で, 主にトリグリセリドにすぐ合成 されたり， $\beta$ 酸化で代謝されたりするので，遊離 の形で肝蔵に到達する量が非常に少ないからでは ないかと考えられる。また, 脂肪酸の代謝は, 大
部分がミトコンドリアで行われており，ペルオキ シゾームはその補助的な役割を持っていると想像 され, そのために比較的高濃度の脂肪酸でのみぺ ルオキシゾーム増殖誘導が引き起こされるのでは ないかと思われる，一方，長鎖の不飽和脂肪酸で あるエルカ酸 $\left(\mathrm{C}_{22}: 1\right)$ は，ミトコンドリアで $\beta$ 酸 化され難く，むしろペルオキシゾームで $\beta$ 酸化さ れる脂肪酸であるが，エルカ酸投与によるペルオ キシゾーム増殖誘導は報告されている ${ }^{14)}$. 強いペ ルオキシゾーム増殖誘導作用が報告されているバ ルプロ酸や2-エチルヘキサン酸は， $\alpha$ 位に大きな 分岐鎖を持つ脂肪酸であり, したがって, $\beta$ 酸化 を受けない脂肪酸である。このようにみてくる と, ペルオキシゾーム増殖誘導活性を有する Xenobiotics は, 脂肪酸とは似て非なる異形の脂 肪酸であるがゆ学に代謝され難く，遊離の形で高 濃度で肝に留まることができるために，増殖誘導 作用を発現するのではないかと考觉を進めること ができる。

\section{5. 代謝されない遊離脂肪酸は実際にペルオキ シゾーム増殖誘導剤であるか}

それならば脂肪酸を，全く代謝されない形態 で，遊離のまま肝に送り込むことができれば，ペ ルオキシゾーム増殖が誘導されるのではないであ ろらか。現実には，このようなことは困難である が，たまたま中鎖脂肪酸であるオクタン酸 $\left(\mathrm{C}_{8}\right)$ の水素原子を, すべてフッ素原子で置き換えたパ ーフルオロオクタン酸が全く代謝されないと言ら 報告があることを知った ${ }^{15)}$. 炭素一フッ素の結合 は, 炭素一水素の結合と比較して, 非常に強く安 定であるので，代謝される部位の水素原子をフッ 
素置換することにより，元の薬物が代謝され難く なることは良く知られている(ブロック効果). また，フッ素原子は水素原子と立体的には注とん ど差がなく，したがって，パーフルオロオクタン 酸の立体構造は, 元のオクタン酸と差がないと考
えることができる (ミミック効果). このように パーフルオロ脂肪酸類は, 遊離の内因性脂肪酸を ミミックする化合物と考兵ることができるので, そのペルオキシン゙ーム増殖誘導作用を調べること は非常に興味深いと考觉た。

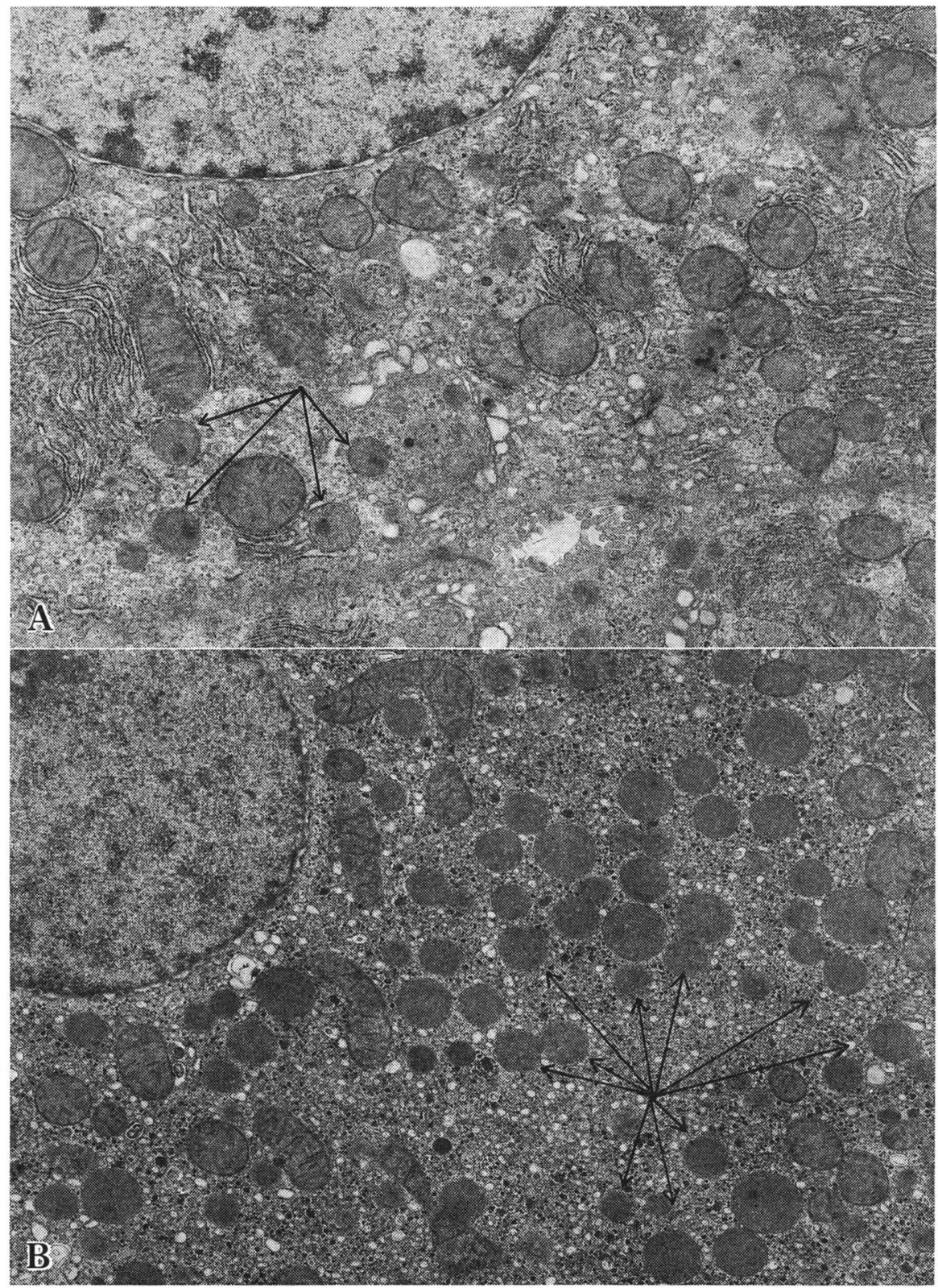

Fig. 3. パーフルオロオクタン酸によるラット肝ペルオキシゾームの増殖誘導

A : コントロール肝の電子顕微鏡写真（倍率10000倍）

コアを持つペルオキシゾームがわずかに認められる (矢印).

$\mathrm{B}$ ：パーフルオロオクタン酸投与後の肝電子顕微鏡写真 (倍率7000倍).

コアのないペルオキシゾームが無数に認められる (一部に矢印). 
そこで入手できるパーフルオロ脂肪酸のうち， 短鎖から中長鎖誘導体であるパーフルオロデカン 酸 $\left(\mathrm{C}_{10}\right)$, パーフルオロオクタン酸 $\left(\mathrm{C}_{8}\right)$ および パーフルオロ酪酸 $\left(\mathrm{C}_{4}\right)$ をラットに投与したとこ ろ, いずれも非常に強いペルオキシゾーム増殖誘 導作用が認められた (Fig. 3 $)^{16,17)}$. その効果は劇 的であり，今まで報告されている増殖誘導剤は， 䬣に混ぜて 2 週間以上投与しなければペルオキシ ゾーム增殖誘導が観察されにくかったのに対し て, パーフルオロ脂肪酸類は, 単回の腹腔内投与 3 日後で十分なペルオキシゾーム増殖誘導が観察 された (特 $\mathrm{C}_{10}$ と $\mathrm{C}_{8}$ ). パーフルオロ酪酸は知ら れている中でもっとも単純なペルオキシゾーム増 殖誘導剤であるが，他の 2 つのもと比較する と，その効果は若干弱かった、扣そらく，炭素鎖 が短い分だけ水溶性が高く, 体外への排泄も速い ためであらうと推察される。ここで特筆しなくて はならない点は, 対照として投与したパーフルオ ロドデカンやパーフルオロオクタンの影響につい てである.カルボキシル基を欠いたこれらのパー フルオロアルカン類には, 全くペルオキシゾーム 増殖誘導能が認められなかった (Table II).この 事実からも，ペルオキシン゙ーム增殖誘導剤はカル ボキシル基を持っていること，すなわち，ごく単 純には脂肪酸類似構造を有することが必須である ことが明らかになった。

\section{CoA エステル型 脂肪酸が ペルオキシ・゙ー 么増殖誘導作用を持つのか}

脂肪酸ではなく, CoA エステル型の脂肪酸が 実際の増殖誘導剤ではないかといら考光方をする 研究者もあり ${ }^{18)}$, 事実クロフィブレートが CoA エステルで一部存在すると言らことも, この考光 を支持している ${ }^{19)}$. 代謝されないとは言光，パー フルオロ脂肪酸類が肝内で一部 CoA エステルの 形で絶対に存在しないと言う保証はない。そこで 生体内で CoA エステルとならない化合物があれ ば, そのペルオキシゾーム増殖誘導能を調ベるこ とにより, 活性型が遊離型であるのか， CoA エ ステル型であるのかを知ることができると考光 た．幸いにして，パーフルオロオクタン酸類似の 物質としてパーフルオロオクタンスルホン酸が市 販されて打り，このものも全く代謝を受けないこ とが報告されていた (Fig. 4) ${ }^{15)}$. 最初われわれ は, この化合物に注目しなかったのであるが，ス ルホン酸は生体内では CoA エステルに活性化さ れないということに着目して，パーフルオロ脂肪 酸に引き続いてそのペルオキシゾーム増殖誘導能 を調べてみた. その結果, パーフルオロオクタン スルホン酸も, パーフルオロ脂肪酸に劣らず強い ペルオキシゾーム増殖誘導剤であることが明らか となった (Table III) ${ }^{20)}$. したがって, ペルオキシ

Table II. パーフルオロ脂肪酸投与後の肝臓ペルオキシゾーム酵素の誘導

\begin{tabular}{|c|c|c|c|}
\hline $\begin{array}{l}\text { 投与した } \\
\text { パーフルオロ化合物a) }\end{array}$ & $\begin{array}{l}\text { 肝 } \text { 重 }{ }^{\text {量 }} \\
\text { 体重) }\end{array}$ & $\begin{array}{c}\text { カタラーゼ } \\
\left(\mu \mathrm{mol}-\mathrm{H}_{2} \mathrm{O}_{2} / \mathrm{min} / \mathrm{mg} \text {-protein }\right)\end{array}$ & $\begin{array}{l}\text { 分子量 } 8 \text { 万蛋白の誘導 } \\
\text { (SDS-PAGE) }\end{array}$ \\
\hline コントロール & $4.75 \pm 0.08$ & $730.3 \pm 33.0$ & - \\
\hline パーフルオロオクタン酸 & $6.90 \pm 0.30^{*}$ & $1143.7 \pm 52.8^{*}$ & + \\
\hline パーフルオロ酪酸 & $4.48 \pm 0.22$ & $1039.8 \pm 121^{*}$ & + \\
\hline パーフルオロオクタン & $4.70 \pm 0.11$ & $741.2 \pm 8.9$ & - \\
\hline
\end{tabular}

a : $0.02 \%$ 含有食で 2 週間飼育 $(n=6)$.

$\mathrm{b}$ : 脂肪酸 $\beta$ 酸化酵素系酵素. ペルオキシゾーム独得のエノイル CoA 水和活性と 3 -ヒドロキシアシル CoA 酸化活性の両活性を同時に持つ二頭酵素.

* : $\mathrm{p}<0.05$.

$\begin{array}{ll}\text { パーフルオロデカン酸: } & \mathrm{CF}_{3} \mathrm{CF}_{2} \mathrm{CF}_{2} \mathrm{CF}_{2} \mathrm{CF}_{2} \mathrm{CF}_{2} \mathrm{CF}_{2} \mathrm{CF}_{2} \mathrm{CF}_{2} \mathrm{COOH} \\ \text { パーフルオロオクタン酸: } & \mathrm{CF}_{3} \mathrm{CF}_{2} \mathrm{CF}_{2} \mathrm{CF}_{2} \mathrm{CF}_{2} \mathrm{CF}_{2} \mathrm{CF}_{2} \mathrm{COOH} \\ \text { パーフルオロ酪酸： } & \mathrm{CF}_{3} \mathrm{CF}_{2} \mathrm{CF}_{2} \mathrm{COOH} \\ \text { パーフルオロオクタンスルフォン酸: } & \mathrm{CF}_{3} \mathrm{CF}_{2} \mathrm{CF}_{2} \mathrm{CF}_{2} \mathrm{CF}_{2} \mathrm{CF}_{2} \mathrm{CF}_{2} \mathrm{CF}_{2} \mathrm{SO}_{3} \mathrm{H}\end{array}$

Fig. 4. パーフルオロ脂肪酸とパーフルオロオクタンスルフォン酸の構造 
Table III. パーフルオロオクタンスルフォン酸投与後の肝臓ペルオキシゾーム酵素の誘導

\begin{tabular}{|c|c|c|}
\hline 酵 & コントロール & $\begin{array}{l}\text { パーフルオロ } \\
\text { オクタンスルフォン酸a) }\end{array}$ \\
\hline カタラーゼ $\left(\mu \mathrm{mol}-\mathrm{H}_{2} \mathrm{O}_{2} / \mathrm{min} / \mathrm{g}\right.$-liver $)$ & $833.0 \pm 69$ & $1450.0 \pm 79^{*}$ \\
\hline カルニチンーアセチル転移酵素（units/g-liver） & $409.0 \pm 19$ & $2796.0 \pm 133^{* *}$ \\
\hline シアン非感受性パルミトイル CoA 酸化酵素 ("I) & $558.0 \pm 40$ & $2733.0 \pm 152^{* *}$ \\
\hline カルニチンーパルミトイル転移酵素（"I） & $1686.0 \pm 37$ & $2846.0 \pm 166^{* *}$ \\
\hline
\end{tabular}

a : $0.02 \%$-パーフルオロオクタンスルフォン酸含有食で 2 週間飼育 $(\mathrm{n}=6)$.

* : $\mathrm{p}<0.05 . \quad * *: \mathrm{p}<0.01$.

ゾーム増殖誘導剂のカルボキシル基は, スルホン 酸基にも置換し得ること, また $\mathrm{CoA}$ のエステル 型ではなく, 遊離型がペルオキシゾーム増殖誘導 を引き起こす活性を有することが明らかとなっ た。

\section{7. 肝ペルオキシ・゙ーム増殖 誘導 威としての 「代謝され難い脂溶性アニオン」}

少し大胆であるが，ペルオキシゾーム増殖誘導 剂に共通する本質的な化学構造を考光てみたい. 今まで述べてきた結果から, 少なくとも次の 3 点 を満足していることが，ペルオキシン゙ーム増殖誘 導剤としての必要条件であろらと考觉られる.

(1) カルボキシル基やスルホン酸基（リン酸基 も?）などを持つアニオンであること，あるいは 生体内で，これらの基を遊離することのでさる官 能基を持っていること（エステル，アルコールな ど).

(2) 少なくとも酪酸 $\left(\mathrm{C}_{4}\right)$ 以上の脂溶性を持つ こと.

(3) 生体内で代謝され難いこと.

この 3 つの特性を一言でまとめれば，「ペルオ キシゾーム増殖誘導剤に共通する本質的な化学構 造は, 代謝され難い脂溶性アニオン構造である.」 と言うことができよう、脂肪酸類似構造を持つこ とが, 活性発現に基本的に必要であると考兄られ るので, 増殖誘導風は脂溶性アニオン構造を必然 的にとることになると考えられる。 また，脂溶性 が高ければ，それだけ体内あるいはターゲットオ 一ガンである肝蔵内に留まりやすくなるはずであ り，代謝され難い性質は，その特性を高めると考 えられる。

このように, (1), (2)の条件は, ペルオキシゾー ム増殖誘導活性発現に真に必要とされるものであ
り, (2), (3)の条件は, これらの薬剤が肝蔵に留ま りやすくするためのものであると言えよう．この 観点から, 今まで報告されているペルオキシゾ 一ム増殖誘導剤の化学構造を見てみると, 全部こ の範疇にはいるものであることがわかる。それぞ れの増殖誘導活性に差異があるのは, それぞれの 脂溶性に差があり, また, 代謝の受け方も異なっ ているからであると考觉られる、以上のような考 点方が正しければ, 各薬剂が脂溶性アニオンの形 で肝蔵内に留まっている時間を比較することによ り, これらのペルオキシン゙ーム増殖誘導剤の活性 を客観的に評価できるものと期待される.

\section{8. おわりに}

ペルオキシゾームは, 甲状腺ホルモンによって も増殖誘導を受けることが知られている ${ }^{21,22)}$ 。し かし，甲状腺を摘出したり，薬物により機能を抑 制した動物に扣いて，クロフィブレート類はペル オキシゾーム増殖を誘導するし，培養肝細胞系で も同様の活性を示すので23,24), これらの薬剤は, 肝細胞に直接作用して増殖誘導効果を発揮してい るものと考觉らる。

一般に, 薬物により細胞中のある酵素めるいは オルガネラが誘導された場合, どのような機構で それが引き起こされているのかについては，まだ 未解決の問題が多い。これに対する共通項的な解 答の一つは, 薬物に対するレセプターを想定する ことである、例えば，チトクローム P-450 のア イソザイムの一つである芳香族炭化水素水酸化酵 素 (AHH) が 2, 3，7，8-Tetrachlorodibenzodioxin (TCDD) によって誘導される現象について は, TCDD に詨するレセプター（Ah レセプタ 一）の存在と, これを介した $\mathrm{AHH}$ 遺伝子の転 写促進機構 (メッセンジャー RNA 量の増加と, 
これに引き続いた $\mathrm{AHH}$ 酵素蛋白量の増加）が 早くから報告されている25). またこれよりも古 く，ステロイドによる酵素誘導現象に対しては， ステロイドレセプターそのものの単離がすでに成 されている。

同様にして，ペルオキシゾーム増殖誘導剤に対 しても, 最近肝臓に和けるレセプターの存在が提 唱されている ${ }^{26,27)}$. こらしたペルオキシゾーム増 殖誘導剤に対するレセプターが実在するとすれ ば，われわれの研究結果から考光て，この蛋白 は，脂溶性基を認識する部分と，ネガティブに荷 電した基を認識する部分とを、リガンド結合部位 に持っているものと想像される。 また，増殖誘導 剤の脂溶性基は多岐にわたっていることから，こ の部分のレセプターにおける認識部位は, 比較的 ブロードな許容性を持っていると推察される.あ るいはレセプター自身が，何種類か存在するのか
も知れない，最近の分子生物学の目ざましい発展 の結果, ペルオキシゾームに含まれる数々の酵素 についても，その遺伝子がすでに取得され，増殖 誘導剂による DNA 転写促進機構の解明に向か って研究が進んでいる ${ }^{28)}$. 近い将来, レセプター も含めて, ペルオキシゾーム増殖誘導機構の全容 が明らかにされるものと期待される。

\section{謝 辞}

本稿に示したわれわれの研究成果は, 三共(秼分 析代謝研究所 - 進藤英世所長, 田中実所次長およ び駒井亨代謝一室室長の御指導, 御鞭 撻 のもと で, 福田邦昭博士, 相場君江, 森いらうみ, 井田(榎 本）美香子各氏との共同研究により得られたもの であり，ここに深謝致します。また有益な御助言 を頂いた東京薬科大学須賀哲弥教授に厚く御礼申 し上げます。

\section{文献}

1) Hess, R., Stäubli, W. and Riess, W. : Nature, (London) $208:$ 856-858 (1965).

2) Reddy, J.K., Warren, J.R., Reddy, M.K. and Lalwani, N.D. : Ann. N. Y. Aca. Sci., 386 : 81-108 (1982).

3) Reddy, J.K., Rao, M.S., Lalwani, N.D., Reddy, M.K., Nemali, M.R. and Alvares, K. : "Peroxisomes in Biology and Medicine" ed. by Fahimi, H.D. and Sies, H., pp. 255-262, Springer-Verlag, Berlin, Heidelberg (1987).

4）渡辺隆史：薬物動態, 1:179-189（1986).

5) Hashimoto, T. : "Peroxisomes in Biology and Medicine" ed. by Fahimi, H.D. and Sies, H., pp. 97-104, Springer-Verlag, Berlin, Heidelberg (1987).

6）小田敏明, 船井恒嘉, 宮嶋裕明, 市山 新: 生化学, 59 : 554 (1987).

7) Lazarow, P.B. and De Duve, C. : Proc. Nat. Acad. Sci. USA, 73 : 2043-2046 (1976)

8) Ishii, H., Fukumori, N., Horie, S. and Suga, T. : Biochim. Biophy. Acta, 617 : 1-11 (1980).

9) Neat, C.E., Thomassen, M.S. and Osmundsen, H. : Biochem. J., $186:$ 369-371 (1980).

10) Horie S., Ishii, H. and Suga, T. : J. Biochem. (Tokyo), $90: 1691-1696$ (1981).

11) Ishii, H., Horie, S. and Suga, T. : J. Biochem. (Tokyo), $87: 1855-1858$ (1980).

12) Ikeda, T., Enomoto, M., Mori, I., Fukuda, K., Komai, T. and Suga, T. : in Abstracts of ISSX/SOT North American Symposium on Endogenous Factors in the Toxicity of Xenobiotics, Clearwater, Florida, USA (1987).

13) Ikeda, T., Enomoto, M., Mori, I., Fukuda, K., Iwabuchi, H., Komai, T. and Suga, T : Xenobiotica, $18:(1988)$, in press.

14) Osmundsen, H. : Ann. N.Y. Aca. Sci. $386: 13-27$ (1982).

15) Johnson, J.D., Gibson, S.J. and Ober, R.E. : in Abstract Paper of First International Symposium on Forign Compounds Metabolism, West Palm Beach, Florida, USA (1983), p. 37.

16）池田敏彦，相場君江，福田邦昭，田中 実：生化学，56：1036 (1984).

17) Ikeda, T., Aiba, K., Fukuda, K. and Tanaka, M. : J. Biochem. (Tokyo), 98 : 475-482 (1985).

18) Christophersen, B., Norseth, J., Thomassen, M.S., Christiansen, E.N., Norum K.R., Osmundsen, H. and Bremer, J. : "Nutritional Evaluation of Long-Chain Fatty 
Acids in Fish Oil” ed. by Barlow, S.M. and Stansby, M.E., pp. 89-139, Academic Press, London (1982).

19) Lygre, T., Aarsaether, N., Stensland, E., Aarsland, A. and Berge, R.K. : $J$. Chromatog., 381 : 95-105 (1986).

20) Ikeda, T., Fukuda, K., Mori, I., Enomoto, M., Komai, T. and Suga, T. : "Peroxisomes in Biology and Medicine" ed. by Fahimi, H.D. and sies, pp. 304308, Springer-Verlag, Berlin, Heidelberg (1987).

21) Just, W.W. and Hartl, F.U. : Hoppe-Seyl. Z. Physiolo. Chem., 364 : 1541-1547 (1983).

22) Fringes, B., Reith, A. and Riede, U. : Ann. N.Y. Acad. Sci., $386: 514-518$ (1982).

23) Gray, T.J.B., Lake, B.G., Foster, J.R. and Gangolli, S.D. : Toxicol. Appl. Pharmacol., 67 : 15-25 (1983).

24) Lake, B.G., Gray, T.J.B., Pelsrijcken, W.R., Beamand, J.A. and Gangolli, S.D. : Xenobiotica, $14: 269-276$ (1984).

25) Nebert, D.W., Eisen, H.J., Negishi, M., Lang, M.A., Hjelmeland, L.M. and Okey, A.B. : Ann. Rer. Pharmacol. Toxicol., 21 : 431-462 (1981).

26) Lalwani, N.D., Fahl, W.E. and Reddy, J.K. : Biochem. Biophys. Res. Communi., $116: 388-393$ (1983).

27] Reddy, J.K. and Rao, M.S. : Trends in Pharmacol. Sci., $7: 438-443$ (1986).

28）土方 誠, 温進坤, 上条桂樹, 石井尚子, 宮沢昌子, 大隅 隆, 橋本 隆: 生化学, $59: 554$ (1987). 